\title{
ORGANIZATIONAL CULTURE IN CLINICAL DEPARTMENTS OF OBSTETRICS-GYNECOLOGY AND NEONATOLOGY: THE NURSES' AND MIDWIVES' OPINION
}

\author{
Janina Ribeliene் $\dot{1}^{1,2}$, Aurelija Blaževičiene் ${ }^{1}$, Rūta Jolanta Nadišauskiene் $\dot{e}^{3}$, Rasa Tameliené2, \\ Aušrelė Kudrevičiené2 $\dot{2}^{2}$ Irena Nedzelskiené $\dot{e}^{4}$, Jūratė Macijauskiené $\dot{e}^{5}$ \\ ${ }^{1}$ Department of Nursing and Care, Lithuanian University of Health Sciences, Kaunas, Lithuania, \\ ${ }^{2}$ Clinical Department of Neonatology, Lithuanian University of Health Sciences, Kaunas, Lithuania, \\ ${ }^{3}$ Clinical Department of Obstetrics and Gynecology, Lithuanian University of Health Sciences, \\ Kaunas, Lithuania, ${ }^{4}$ Department of Dental and Oral Diseases, Lithuanian University \\ of Health Sciences, Kaunas, Lithuania, ${ }^{5}$ Faculty of Nursing, Lithuanian University of \\ Health Sciences, Kaunas, Lithuania
}

Keywords: organizational culture, obstetrics-gynecology, neonatology, healthcare institution

\begin{abstract}
Summary
Background. Institutions that provide services in the fields of obstetrics-gynecology and neonatology treat highly vulnerable patient groups, and thus assurance of the quality of healthcare and the safety of the patients is of utmost importance. The type of the organizational culture at a healthcare institution determines the organization's abilities to develop, achieve better results, initiate changes, and implement new methods. The evaluation of organizational culture in such institutions would help to understand and improve patient safety and satisfaction with the healthcare services as well as the effectiveness of the activity of healthcare institutions.

The aim of the study was to identify the type of the organizational culture at a healthcare institution that provides services in the fields of obstetrics-gynecology and neonatology based on the evaluation of nurses' and midwives' opinions.

Summary of the work. The evaluation of the nurses' and midwives' opinions about the organizational culture was performed by using the Organizational Culture Assessment Instrument (OCAI). The overall response rate to the survey was $100 \%(\mathrm{n}=233)$.

Summary of the results. The results of the study showed that during the studied period, the Hierarchy culture predominated. The analysis of the components
\end{abstract}

Dominant Characteristics, Organizational Leadership, Organization Glue, and Strategic Emphases revealed the presence of various types of organizational culture, with the Hierarchy culture (D) being dominant. The analysis of the components Management of Employees and Criteria of Success showed that during the studied period, various culture types existed in the studied institution, with the Clan culture (A) being dominant. In the Hierarchy culture, the analysis of the components Dominant Characteristics, Organizational Leadership, Strategic Emphases, and Criteria of Success revealed that significantly greater differences between the Preferred and Now mean evaluations were in the neonatal departments.

Conclusion. According to the nursing staff, the Hierarchy culture type was predominant in the studied healthcare institution that provides services in the fields of obstetrics-gynecology and neonatology. However, the respondents also would prefer a trend towards a friendlier (the Clan culture) and more creative (the Adhocracy culture) work environment.

\section{Introduction}

Organizational culture is a social phenomenon that exists in every organization. This is a set of values, beliefs, norms, rules, and roles that affects an organization's activity and results. Close associations have been found between organizational culture and patient safety and satisfaction with the healthcare services as well as the effectiveness of the activity of healthcare institutions [1-3]. A number of studies have 
shown that organizational culture is one of the main factors that affect changes implemented for the improvement of patient safety and the quality of the provided services [4-8].

Nursing personnel in healthcare institutions closely cooperate with patients ant may positively or negatively affect the overall organizational culture of a healthcare institution $[9,10]$. The evaluation of the nurses' opinion about the organizational culture may help to identify the features of an institution's organizational culture as well as the effectiveness of these features in promoting the desirable organizational processes and results [5]. Institutions that provide services in the fields of obstetrics-gynecology and neonatology treat highly vulnerable patient groups, and thus assurance of the quality of healthcare and the safety of the patients is of utmost importance. However, organizational culture in such institutions is still rarely analyzed, and data about the predominant types of organizational culture in such healthcare institutions are insufficient.

The aim of our study was to identify the type of the organizational culture at a healthcare institution that provides services in the fields of obstetrics-gynecology and neonatology based on the evaluation of nurses' and midwives' opinions.

\section{Materials and Methods}

Setting and sample. This descriptive cross-sectional study was conducted in Lithuania during May-July 2017. The subjects of the study $(\mathrm{n}=233)$ were nurses and midwives who worked at a university hospital X (Lithuania) that provides services in the fields of obstetrics-gynecology and neonatology. This hospital houses a Labor and Delivery Unit, an Obstetrics Unit, a Gynecology Unit, an Adult Intensive Care Unit, an Operating Room ( $\mathrm{n}=131$ ), a Neonatal Intensive Care Unit (NICU), and Intermediate Care units ( $\mathrm{n}=102)$.

Instruments. The organizational culture was evaluated by applying the Organizational Culture Assessment Instrument (OCAI) designed by Cameron and Quinn [11]. This instrument consists of two main dimensions defining an organization's efficiency. One dimension defines differences between effectiveness criteria that reflect flexibility, discretion, and dynamism from criteria that reflect stability, order, and control. The second dimension defines differences between effectiveness criteria that reflect internal orientation, integration, and unity (internal focus) from criteria that reflect external orientation, differentiation, and rivalry (external focus). Combinations of these dimensions compose four different organization types reflecting the values of an organization's activity. The effectiveness criteria help to identify what is important for people in relation to enterprise performance or defines what is perceived as good or correct

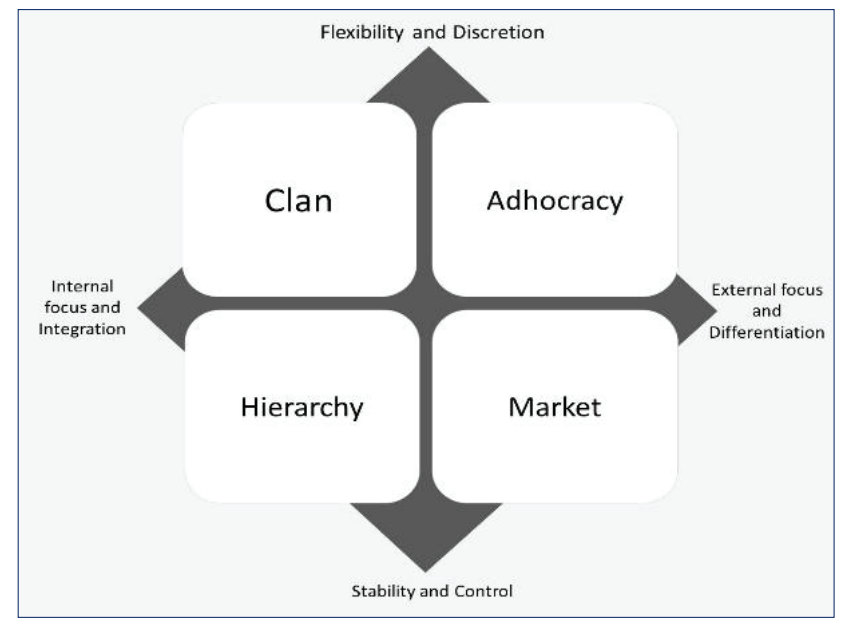

Fig. 1. Factor structure of the OCAI reflective of the Competing Values Framework [11].

(Fig. 1) [11].

Possible organization types:

Clan culture (A) defines a friendly workplace where the employees have similar values. Such organization is similar to a family. In an organization with such culture type, the leaders assume the role of mentors, advisors - and sometimes fathers. Loyalty and traditions unite the organization, and the employees are highly committed to it. Such organization emphasizes each employee's significant long-term experience, and much attention is paid to harmonious teamwork.

Adhocracy culture (B) defines a dynamic organization where creativity predominates. The leaders are innovators willing to take risks. Organizations with this culture type experiment by implementing new methods and initiating changes. Attention is focused on new knowledge, changes, and new challenges. The success of such organization is based on the provision of unique and original services.

Market culture (C) is a results-oriented organization where the employees compete with each other and are achievement-oriented. The leaders are domineering and expect the best results from their employees. Attention is focused on competition and achieving overambitious goals.

Hierarchy culture (D) is characterized by a formal and structured work environment where attention is focused on procedures and regulations. The leaders are good coordinators and organizers who attribute the greatest importance to smooth functioning of the organization, stability, smooth scheduling, and low costs. Attention is focused on ensuring the employees' occupation.

The OCAI questionnaire consists of six components. Each component is analyzed on the basis of four statements that reflect organizational culture types A, B, C, and D (Table 
Table 1. Components $(n=6)$ and statements $(n=24)$ of the OCAI instrument [11].

\section{1. $\quad$ Dominant Characteristics}

A $\quad$ The organization is a very personal place. It is like an extended family. People seem to share a lot of themselves.

B $\quad$ The organization is a very dynamic and entrepreneurial place. People are willing to stick their necks out and take risks.

C $\quad$ The organization is very results-oriented. A major concern is with getting the job done. People are very competitive and achievement-oriented.

\begin{tabular}{lll}
\hline $\mathrm{D}$ & The organization is a very controlled and structured place. Formal procedures generally govern what
\end{tabular} people do.

Total

2. $\quad$ Organizational Leadership

A $\quad$ The leadership in the organization is generally considered to exemplify mentoring, facilitating, or nurturing.

B $\quad$ The leadership in the organization is generally considered to exemplify entrepreneurship, innovation, or risk taking.

C $\quad$ The leadership in the organization is generally considered to exemplify a no-nonsense, aggressive, results-oriented focus.

D The leadership in the organization is generally considered to exemplify coordinating, organizing, or smooth-running efficiency.

\section{Total}

3. $\quad$ Management of Employees

A $\quad$ The management style in the organization is characterized by teamwork, consensus, and participation.

B $\quad$ The management style in the organization is characterized by individual risk taking, innovation, freedom, and uniqueness.

C The management style in the organization is characterized by hard-driving competitiveness, high demands, and achievement.

D $\quad$ The management style in the organization is characterized by security of employment, conformity, predictability, and stability in relationships.

\section{Total}

4. $\quad$ Organization Glue

A $\quad$ The glue that holds the organization together is loyalty and mutual trust. Commitment to this organization runs high.

B $\quad$ The glue that holds the organization together is commitment to innovation and development. There is an emphasis on being on the cutting edge.

C The glue that holds the organization together is the emphasis on achievement and goal accomplishment.

\begin{tabular}{|l|l|}
\hline $\mathrm{D}$ & The glue that holds the organization together is formal rules and policies. Maintaining a smooth
\end{tabular} running organization is important.

Total

5. $\quad$ Strategic Emphases

A The organization emphasizes human development. High trust, openness, and participation persist.

B $\quad$ The organization emphasizes acquiring new resources and creating new challenges. Trying new things and prospecting for opportunities are valued.

C The organization emphasizes competitive actions and achievement. Hitting stretch targets and winning in the marketplace are dominant.

D The organization emphasizes permanence and stability. Efficiency, control, and smooth operations are important.

\begin{tabular}{|l|l|l|}
\hline & Now & Preferred \\
\hline & & \\
\hline & & \\
\hline 100 & 100 \\
\hline
\end{tabular}

Now $\quad$ Preferred




\begin{tabular}{|c|c|c|c|}
\hline \multicolumn{2}{|c|}{ Total } & \multirow{2}{*}{\begin{tabular}{|l|}
100 \\
Now \\
\end{tabular}} & \multirow{2}{*}{$\begin{array}{l}100 \\
\text { Preferred }\end{array}$} \\
\hline 6. & Criteria of Success & & \\
\hline $\mathrm{A}$ & $\begin{array}{l}\text { The organization defines success on the basis of the development of human resources, teamwork, } \\
\text { employee commitment, and concern for people. }\end{array}$ & & \\
\hline B & $\begin{array}{l}\text { The organization defines success on the basis of having the most unique or newest products. It is a } \\
\text { product leader and innovator. }\end{array}$ & & \\
\hline $\mathrm{C}$ & $\begin{array}{l}\text { The organization defines success on the basis of winning in the marketplace and outpacing the com- } \\
\text { petition. Competitive market leadership is key. }\end{array}$ & & \\
\hline $\mathrm{D}$ & $\begin{array}{l}\text { The organization defines success on the basis of efficiency. Dependable delivery, smooth scheduling, } \\
\text { and low-cost production are critical. }\end{array}$ & & \\
\hline \multicolumn{2}{|c|}{ Total } & 100 & 100 \\
\hline
\end{tabular}

Table 2. Respondents' characteristics.

\begin{tabular}{|c|c|c|c|c|}
\hline Characteristics & $\begin{array}{c}\text { Total } \\
\mathrm{n}=233\end{array}$ & $\begin{array}{c}\text { Obstetrics and } \\
\text { Gynecology units } \\
n=131\end{array}$ & $\begin{array}{c}\text { Neonatology } \\
\text { units } \\
n=102\end{array}$ & $\mathrm{p}$ \\
\hline \multicolumn{5}{|l|}{ Sex, n (\%) } \\
\hline $\begin{array}{l}\text { Male } \\
\text { Female }\end{array}$ & $\begin{array}{c}2(0.9) \\
231(99.1)\end{array}$ & $\begin{array}{c}0 \\
130(100)\end{array}$ & $\begin{array}{c}2(1.9) \\
101(98.1)\end{array}$ & 0.2 \\
\hline \multicolumn{5}{|l|}{ Age (years), n (\%) } \\
\hline $\begin{array}{l}40 \text { and less } \\
41-45 \\
46-51 \\
52 \text { or more }\end{array}$ & $\begin{array}{l}53(22.7) \\
62(26.6) \\
58(24.9) \\
60(25.8) \\
\end{array}$ & $\begin{array}{l}42(32.3) \\
37(28.5) \\
23(17.7) \\
28(21.5)\end{array}$ & $\begin{array}{l}11(10.7) \\
25(24.3) \\
35(34.0) \\
32(31.1)\end{array}$ & $\begin{array}{c}\chi^{2}=20.349, \mathrm{df}=3, \\
\mathrm{p}<0.001\end{array}$ \\
\hline \multicolumn{5}{|l|}{ Staff position, n (\%) } \\
\hline $\begin{array}{l}\text { Midwife } \\
\text { Anesthetist and intensive care nurse } \\
\text { Operating room nurse } \\
\text { Nurse }\end{array}$ & $\begin{array}{l}62(26.6) \\
71(30.5) \\
18(7.7) \\
82(35.2) \\
\end{array}$ & $\begin{array}{l}61(46.9) \\
30(23.1) \\
18(13.8) \\
21(16.2) \\
\end{array}$ & $\begin{array}{c}1(1.0) \\
41(39.8) \\
0 \\
61(59.2) \\
\end{array}$ & $\begin{array}{c}\chi^{2}=95.434, \mathrm{df}=3, \\
\mathrm{p}<0.001\end{array}$ \\
\hline \multicolumn{5}{|l|}{ Professional experience (years), n (\%) } \\
\hline $\begin{array}{l}\text { Less than } 1 \\
1-5 \\
6-10 \\
11-15 \\
16-20 \\
21 \text { or more }\end{array}$ & $\begin{array}{c}3(1.3) \\
28(12.0) \\
13(5.6) \\
10(4.3) \\
151(64.8)\end{array}$ & $\begin{array}{c}3(2.3) \\
20(15.4) \\
13(10.0) \\
6(4.6) \\
13(10.0) \\
75(57.7) \\
\end{array}$ & $\begin{array}{c}0 \\
8(7.8) \\
0 \\
4(3.9) \\
15(14.6) \\
76(73.8) \\
\end{array}$ & $\begin{array}{c}\chi^{2}=18.816, d f=5, \\
p=0.002\end{array}$ \\
\hline
\end{tabular}

1). When filling out the questionnaire, the respondents have to distribute 100 points among four statements that best reflect their organization at present (Now); another 100 points have to be distributed among statements that describe what the organization should look like in 5 years (Preferred). The average score is calculated for each form of organizational culture and is presented graphically (Table 1).

Data collection. The data for the study were collected from May to July 2017. One of the authors personally distributed the questionnaires to all 233 eligible midwives and nurses at the clinical departments during work hours from May 1 to July 1, 2017. The overall response rate to the survey was $100 \%(\mathrm{n}=233)$. The participants indicated their age, sex, current workplace, staff position, and professional experience (Table 2).

Ethical concerns. This study was approved by the decision of Kaunas Regional Biomedical Research Ethics Committee passed at a Committee session on February 2, 2017 (protocol No. BE-2-15). Research was carried out in accordance with the ethical principles of scientific research, the Declaration of Helsinki, as well as the Code of Ethics of the Lithuanian Social Research Center (LSRC).

Statistical Analysis. Statistical analysis was performed with software SPSS version 22. All parametric data were expressed as means and standard deviations (M(SD)). The interdependence of qualitative evidence was evaluated by 
the Chi-squared $\left(\chi^{2}\right)$ criterion. Student's $t$ test was used to compare quantitative values of two independent samples. For quantitative dependent values, Student's $t$ paired test was used. A p value of 0.05 or less was considered statistically significant.

\section{Results}

Population. Of the studied sample, 27\% were midwives, and $73 \%$ were nurses. Over one-half $(56 \%)$ of the respondents worked in Obstetrics and Gynecology units, and 44\% of the respondents worked in Neonatology units. The respondents' mean (SD) age was 44.9 (10.0) years (min - 22 years, max -67 years, median -46.0 years), and $76.8 \%$ of the respondents had 16-year or longer professional experience (Table 2).

Organizational culture types in a healthcare institution that provides services in the fields of obstetricsgynecology and neonatology. Figure 2 presents the results

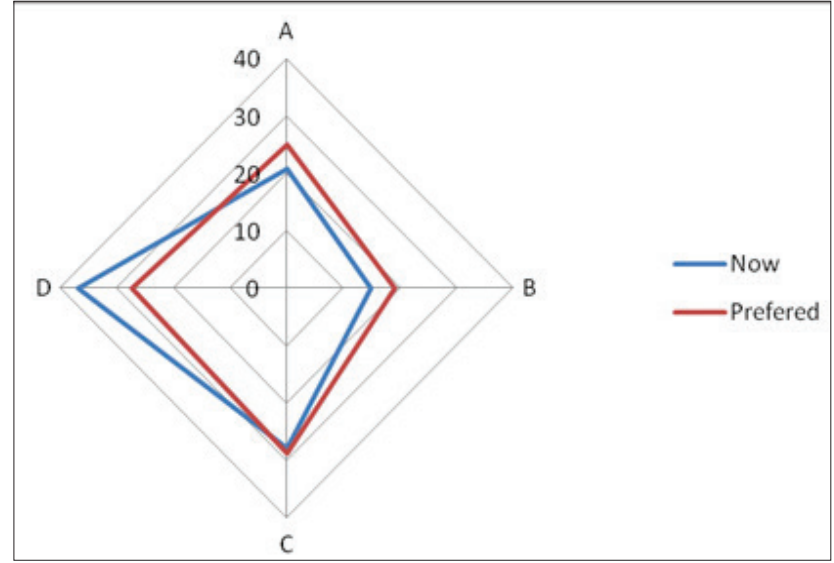

Fig. 2. Results of assessment of the Now and Preferred cultural state using the OCAI.

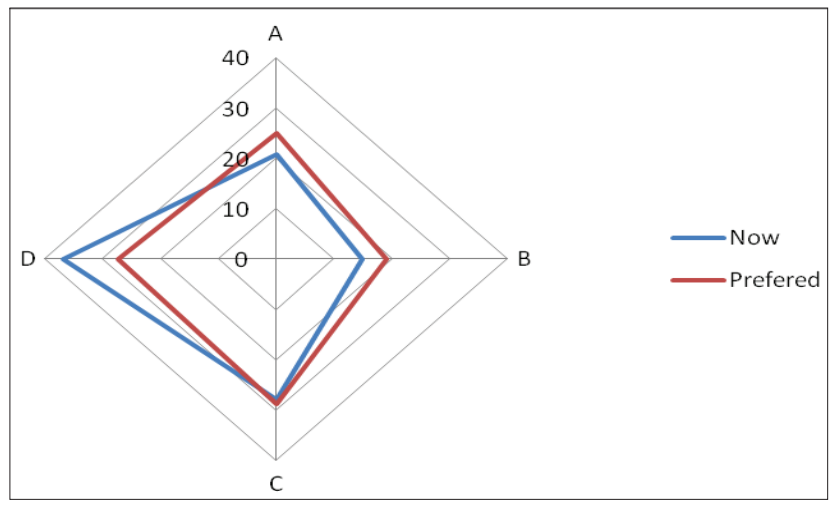

Fig. 3. Results of the assessment of the organizational culture component. Dominant Characteristics (Now and Preferred). of the present and the preferred state of the institution with mean evaluations in each dimension. The means were the following: Clan culture - 20.7, Adhocracy culture - 14.8, Market culture - 27.8, and Hierarchy culture - 36.7. This means that the Hierarchy culture (D) predominated in the studied institution.

We analyzed individual components for the organizational culture. Figure 3 presents the main characteristics of an organization. Our study showed that the Market (C) and the Hierarchy (D) cultures were prevalent, the latter being the dominant one. The evaluation scores of statements A and B in the Preferred section were significantly higher than in the Now section $(\mathrm{p}<0.05)$. The evaluation score of statement $\mathrm{D}$ in the Preferred section was significantly lower than in the Now section $(\mathrm{p}<0.05)$.

Figure 4 presents the characteristics of Organizational Leadership. During the studied period, the Clan (A) and Hierarchy (D) cultures were prevalent, the Hierarchy (D) culture being the dominant one. The evaluation scores of statements

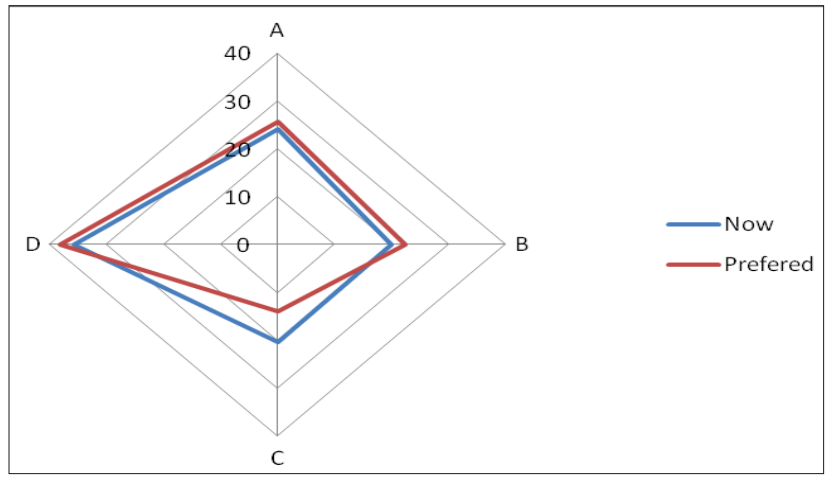

Fig. 4. Results of the assessment of the organizational culture component. Organizational Leadership (Now and Preferred).

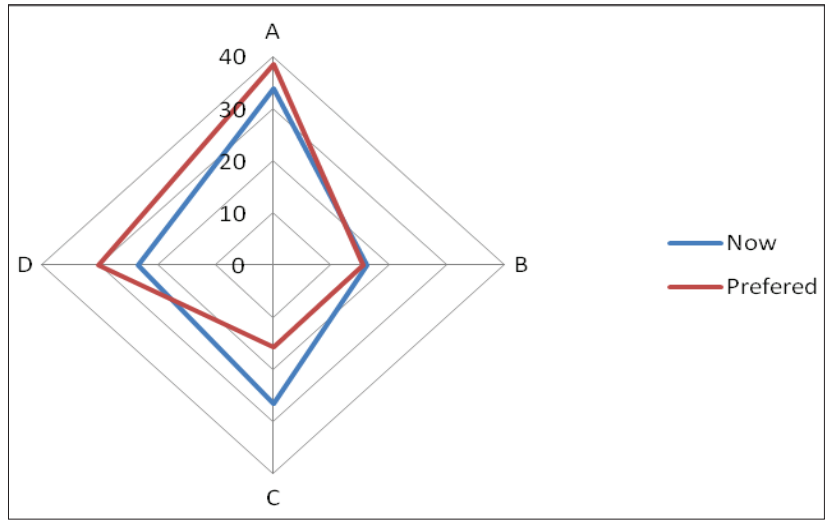

Fig. 5. Results of the assessment of the organizational culture component. Management of Employees (Now and Preferred). 
A and B in the Preferred section were significantly higher than in the Now section $(\mathrm{p}<0.05)$. The evaluation score of statement $\mathrm{C}$ in the Preferred section was significantly lower than in the Now section $(\mathrm{p}<0.05)$.

Figure 5 presents the characteristics of the Management of Employees. During the studied period, the Clan (A) and Market (C) cultures were prevalent, the former being the dominant one. The evaluation scores of statements A and D in the Preferred section were significantly higher than in the Now section $(\mathrm{p}<0.05)$. The evaluation score of statement $\mathrm{C}$ in the Preferred section was significantly lower than in the Now section $(\mathrm{p}<0.05)$.

Figure 6 presents the characteristics of the Organization Glue. During the studied period, the Hierarchy (D) and Clan (A) cultures were prevalent, the Hierarchy (D) culture being the dominant one. The evaluation score of statement $\mathrm{A}$ in the Preferred section was significantly higher than in the Now section $(\mathrm{p}<0.05)$. The evaluation scores of statements B and $\mathrm{D}$ in the Preferred section were significantly lower than in the Now section $(\mathrm{p}<0.05)$.

Figure 7 presents the characteristics of the Strategic Emphases. During the studied period, the Adhocracy (B), the Market (C), and the Hierarchy (D) cultures were prevalent, the Hierarchy (D) culture being the dominant one. The evaluation scores of statements A and B in the Preferred section were significantly higher than in the Now section $(\mathrm{p}<0.05)$. The evaluation scores of statements $\mathrm{C}$ and D in the Preferred section were significantly lower than in the Now section $(\mathrm{p}<0.05)$.

Figure 8 presents the characteristics of the Criteria of Success. During the studied period, the Clan (A) and the Adhocracy (B) cultures were prevalent, the Clan (A) culture being the dominant one. The evaluation score of statement $\mathrm{A}$ in the Preferred section was significantly higher than in the

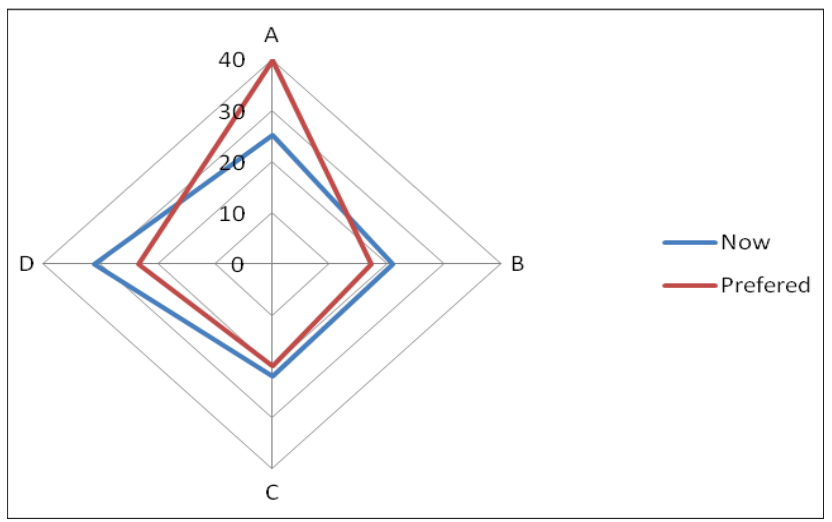

Fig. 6. Results of the assessment of the organizational culture component. Organization Glue (Now and Preferred).
Now section $(\mathrm{p}<0.05)$. The evaluation scores of statements $\mathrm{C}$ and D in the Preferred section were significantly lower than in the Now section $(\mathrm{p}<0.05)$.

\section{Discussion}

To indentify the dominant type of organizational culture, to evaluate its influence on goal attainment, and to highlight possible improvements, a detailed analysis of organizational culture is required. Each institution that provides healthcare services has its own specific organizational culture. Most commonly, several types of culture exist in an organization, but one of them is dominant. However, there is no single ideal culture. All culture types have their positive and negative features [11].

In general, our findings showed that during the studied period, the Hierarchy culture type (D) predominated in the selected healthcare institution that provides services in the fields of obstetrics-gynecology and neonatology. The analysis of the Dominant Characteristics, Organizational Leadership,

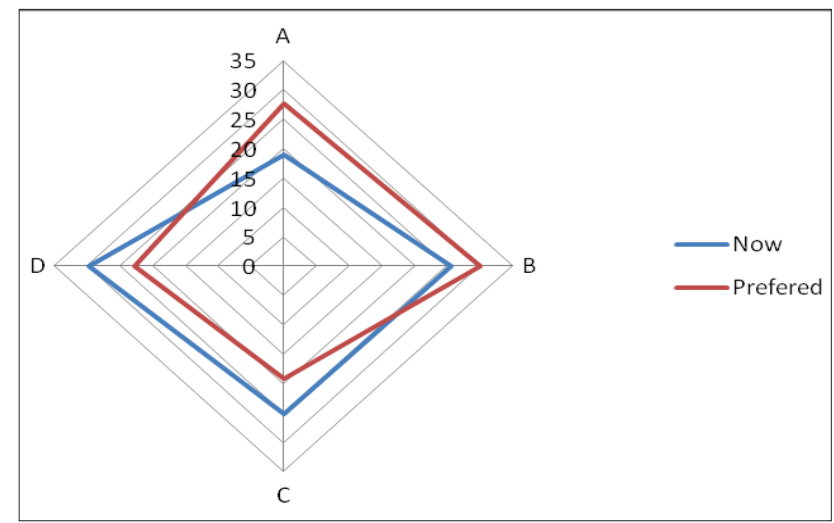

Fig. 7. Results of the assessment of the organizational culture component. Strategic Emphases (Now and Preferred).

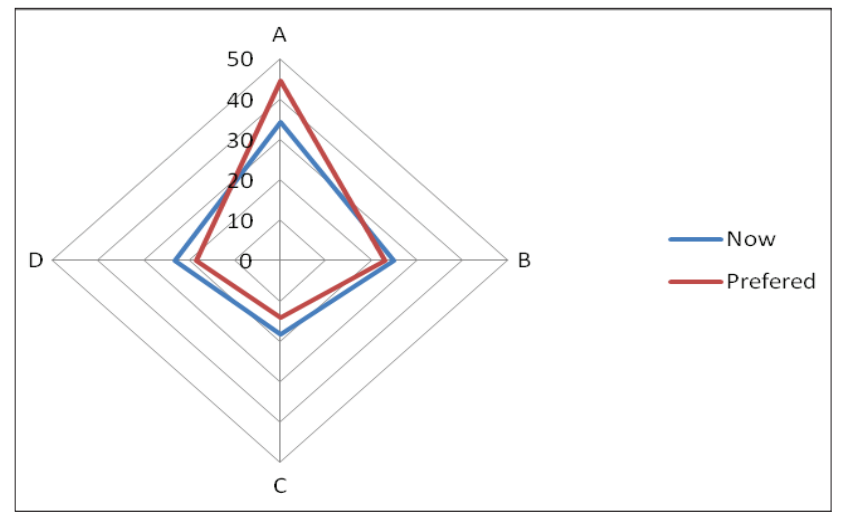

Fig. 8. Results of the assessment of the organizational culture component. Criteria of Success (Now and Preferred). 
Organization Glue, and Strategic Emphases components revealed the predominance of the Hierarchy culture type (D). This means that the studied institution is an organization with a very high level of control and a highly defined structure where formal procedures generally govern what people do. The leadership in the organization is generally considered to exemplify coordinating, organizing, or smooth-running efficiency. The glue that holds the organization together is formal rules and policies. Maintaining a smooth running organization is important. The organization emphasizes permanence and stability. Efficiency, control, and smooth operations are important [11]. The analysis of the Management of Employees and Criteria of Success components revealed the predominance of the Clan (A) culture during the studied period. The management style in the organization is characterized by teamwork, consensus, and participation. The organization defines success on the basis of the development of human resources, teamwork, employee commitment, and concern for people [11]. A number of researchers who analyzed organizational culture in healthcare institutions also found the predominance of the Hierarchy culture or the presence of several culture types with the Hierarchy culture being the dominant one [12-14]. Velanovich et al. analyzed organizational culture in The Department of Surgery. The researchers found that during the studied period, Hierarchy and Market cultures predominated in that department [15]. Scammon et al. analyzed organizational culture in ten primary healthcare institutions and found that Hierarchy and Clan cultures were predominant [16].

The findings of our study showed that the nursing personnel saw the Clan culture as the preferred organizational culture type. The respondents would prefer a friendlier work environment where each employee's long-term experience would be significant, and where more attention would be paid to harmonious teamwork. Leadership should be friendlier and based on tutoring, advice, cooperation, and teamwork, reducing demands and competitiveness. According to the respondents, an organization should be glued by loyalty, mutual trust, and commitment to the organization. They would prefer the organization to base its strategic emphases on trust, open communication, and cooperation, and to define the success by the effectiveness of the work. The respondents were willing to participate in the implementation of new methods, initiating changes, and acquiring new knowledge, and they would prefer innovative leadership in order to initiate changes (Adhocracy culture). According to a number of studies, respondents who work in healthcare institutions would prefer the organizational culture to be oriented towards Clan culture [14], Clan and Market [13], and Clan and Adhocracy [15] culture types.
The dominating type of organizational culture determines the organization's possibilities to develop, achieve better results, initiate changes [17], and implement new methods [18]. A number of researchers found that the predominant organizational culture directly influences the personnel's job satisfaction [16, 19, 20], work effectiveness [20], patient outcomes [8], and patient safety [21]. Brazil K. et al. analyzed organizational culture in 36 primary healthcare centers that provide pediatric services. They found that the Clan culture was positively associated with both satisfaction and perceived effectiveness. Conversely, the Hierarchy and Market cultures were negatively associated with job satisfaction, perceived effectiveness [20], and practice level competitiveness [19]. Market culture was negatively associated with the personnel's job satisfaction, human resources, and price competition. The researchers did not find any association between Adhocracy culture and job satisfaction parameters [19].

This study is the first one in Lithuania to investigate the nursing staff's opinion about the organizational culture at a tertiary inpatient healthcare institution that provides services in the fields of obstetrics-gynecology and neonatology. The study, however, has several limitations. The findings of this study were obtained by investigating a small sample. The subjects were midwives and nurses of a single university hospital X (Lithuania) that provides services in the fields of obstetrics-gynecology and neonatology. For this reason, the obtained results do not reflect the opinion about the current and the preferred organizational culture among the nursing staff of all Lithuanian healthcare institutions that provide services in the fields of obstetrics-gynecology and neonatology.

\section{Conclusion}

According to the nursing personnel, the Hierarchy culture type predominated in the studied healthcare institution that provides services in the fields of obstetrics-gynecology and neonatology. However, the respondents preferred to see this culture type transform into a friendlier (the Clan culture) and more creative (the Adhocracy culture) work environment in the future.

\section{Acknowledgements}

The authors wish to thank all midwifes and nurses who kindly participated in the study.

Declaration of interest statement

The authors report no conflicts of interest.

\section{References}

1. Zhou P, Bundorf K, Le Chang J, Huang JX, Xue D. Organizational culture and its relationship with hospital performance in public hospitals in China. Health Serv Res 2011; 46(6pt2):2139-2160. 
https://doi.org/10.1111/j.1475-6773.2011.01336.x

2. Jacobs E, Roodt G. Organizational culture of hospitals to predict turnover intentions of professional nurses. Health SA Gesondheid. J Interdiscipl Health Sci 2008;13:63-78.

https://doi.org/10.4102/hsag.v13i1.258

3. Scott T, Mannion R, Davies H, Marshall M. The quantitative measurement of organizational culture in health care: a review of the available instruments. Health Serv Res 2003;38:923-945. https://doi.org/10.1111/1475-6773.00154

4. Curry LA, Brault MA, Linnander EL, McNatt Z, Brewster AL, Cherlin E, Flieger SP, Ting HH, Bradley EH. Influencing organisational culture to improve hospital performance in care of patients with acute myocardial infarction: a mixed-methods intervention study. BMJ Qual Saf 2018;27:207-217. https://doi.org/10.1136/bmjqs-2017-006989

5. Rovithis M, Linardakis M, Rikos N, Merkouris A,Patiraki E,Philalithis A. Organizational culture among nurses working in the public health sector on the Island of Crete - Greece. Health Science Journal 2016;10(2):14.

6. Carroll JS, Quijada MA. Redirecting traditional professional values to support safety: changing organisational culture in health care. Qual Saf Health Care 2004;13 (Suppl II):ii16-ii21. doi: 10.1136/qshc.2003.009514.

https://doi.org/10.1136/qshc.2003.009514

7. Ukawa N, Tanaka M, Morishima T, Imanaka Y; Organizational culture affecting quality of care: guideline adherence in perioperative antibiotic use, International Journal for Quality in Health Care 2015;27(1):37-45.

https://doi.org/10.1093/intqhe/mzu091

8. Braithwaite J, Herkes J, Ludlow K, Testa L, Lamprell G. Association between organisational and workplace cultures, and patient outcomes: systematic review. BMJ Open 2017;7(11):e017708. https://doi.org/10.1136/bmjopen-2017-017708

9. Gifford BD, Zammuto RF, Goodman EA. The relationship between hospital unit culture and nurses' quality of work life. J Healthc Manag 2002;47:13-25.

https://doi.org/10.1097/00115514-200201000-00005

10. Draper DA, Felland LE, Liebhaber A, Melichar L. The role of nurses in hospital quality improvement. Res Brief 2008;1-8.

11. Cameron, Kim S. Diagnosing and changing organizational culture : based on the competing values framework/Revised ed. 2006 by John Wiley \& Sons, Inc. ISBN-13 978-0-7879-8283-6.

12. Vegro TC1, Rocha FL2, Camelo SH2, Garcia AB1. Organizational culture of a private hospital. Rev Gaucha Enferm. 2016;37(2):e49776. doi: 10.1590/1983-1447.2016.02.49776. https://doi.org/10.1590/1983-1447.2016.02.49776

13. Acar AZ, Acar P. Organizational culture types and their effects on organizational performance in Turkish hospitals. Emerging Markets Journal 2014;3:18-31. http://dx.doi.org/10.5195/ emaj.2014.47

https://doi.org/10.5195/EMAJ.2014.47
14. Traczyńska, K, Kunecka D. Organizational culture in nursing teams based on the example of a particular hospital. Progress in Health Sciences 2018;8(1):46-54.

15. Velanovich V, Harringto MA, Smith DJ. Toward understanding culture and judgment in an Academic Surgical Department with Assessments using the Competing Values Framework and hartman value profile: a case study. Clin Surg 2016;1:1264.

16. Scammon DL, Tabler J, Brunisholz K. et al. Organizational culture associated with provider satisfaction. J Am Board Fam Med 2014;27(2):219-28. https://doi.org/10.3122/jabfm.2014.02.120338

17. Hung DY1, Leidig R, Shelley DR.What's in a setting?: Influence of organizational culture on provider adherence to clinical guidelines for treating tobacco use. Health Care Manage Rev. 2014;39(2):154-63.

https://doi.org/10.1097/HMR.0b013e3182914d11

18. Dodek P1, Cahill NE, Heyland DK.The relationship between organizational culture and implementation of clinical practice guidelines: a narrative review. JPEN J Parenter Enteral Nutr. 2010;34(6):669-74.

https://doi.org/10.1177/0148607110361905

19. Zazzali JL, Alexander JA, Shortell SM, Burns LR. Organizational culture and physician satisfaction with dimensions of group practice. Health Serv Res 2007;42(3 Pt 1):1150-76.

https://doi.org/10.1111/j.1475-6773.2006.00648.x

20. Brazil K, Wakefield DB, Cloutier MM, Tennen H, Hall CB. Organizational culture predicts job satisfaction and perceived clinical effectiveness in pediatric primary care practices. Health Care Manage Rev 2010 Oct-Dec;35(4):365-71. doi: 10.1097/ HMR.0b013e3181edd957.

https://doi.org/10.1097/HMR.0b013e3181edd957

21. Hartmann CW, Meterko M, Rosen AK, Shibei Zhao, Shokeen P, Singer S, Gaba DM. Relationship of hospital organizational culture to patient safety climate in the Veterans Health Administration. Medical Care Research and Review 2009;66(3):320-338. https://doi.org/10.1177/1077558709331812

\section{ORGANIZACIJOS KULTŪRA AKUŠERIJOS- GINEKOLOGIJOS IR NEONATOLOGIJOS SKYRIUOSE: \\ SLAUGYTOJŲ IR AKUŠERIŲ POŽIŪRIS}

J.Ribelienė, A.Blaževičienė, R.J.Nadišauskienė, R.Tamelienė, A.Kudrevičienė, I.Nedzelskienė, J.Macijauskienė

Raktažodžiai: organizacinè kultūra, akušerija, ginekologija, neonatologija, gydymo įstaiga.

Santrauka

İvadas. Akušerijos, ginekologijos ir neonatologijos paslaugas teikiančiose gydymo ịstaigose gydomos labai pažeidžiamos pacientų grupès, todèl ypač svarbu užtikrinti puikią sveikatos priežiūros kokybę ir pacientų saugumą. Nuo organizacinès kultūros gydymo įstaigoje tipo priklauso organizacijos galimybès tobulèti, pasiekti geresnių rezultatų, daryti pokyčius, diegti naujas 


\section{8}

metodikas. Organizacinès kultūros įvertinimas šiose gydymo ịstaigose padètų suprasti ir pagerinti pacientų saugumą, jų pasitenkinimą sveikatos priežiūros paslaugomis, sveikatos priežiūros ịstaigų veiklos efektyvumą.

Darbo tikslas: nustatyti organizacijos kultūrą akušerijos, ginekologijos ir neonatologijos paslaugas teikiančioje gydymo įstaigoje, vertinant slaugytojų ir akušerių nuomonę.

Tyrimo metodika. Naudojant organizacijos kultūros vertinimo klausimyną (OCAI) buvo vertinama slaugytojų ir akušerių nuomonè apie organizacinę kultūrą. Atsako dažnis $100 \%$ (n=233.

Rezultatai. Tiriamuoju laikotarpiu vyrauja hierarchijos kultūra. Analizuodami pagrindinių charakteristikų, organizacijos lyderytės, organizacijos vienybès, strateginių akcentų komponentus nustateme, kad tiriamuoju laikotarpiu akušerijos, ginekologijos ir neonatologijos skyriuose vyrauja ịvairūs kultūros tipai, dominuojant hierarchinei (D) kultūrai. Analizuodami darbuotojų adminis- travimo ir sekmės kriterijų komponentus, nustatėme kad tiriamuoju laikotarpiu vyrauja įvairūs kultūros tipai, dominuojant Klano (A) kultūrai. Komponentų pagrindinių charakteristikų, organizacijos lyderytės, strateginių akcentų ir sėkmės kriterijų hierarchinès kultūros teiginio "norimas" ir "dabar" vidurkių pokyčiai buvo reikšmingai didesni naujagimių skyriuose.

Išvados. Slaugos personalo nuomone, akušerijos, ginekologijos ir neonatologijos paslaugas teikiančioje gydymo ịstaigoje dominuoja hierarchinès kultūros tipas. Tačiau respondentai vertintų tendenciją ị draugiškesnę (klano kultūra) ir kūrybiškesnę (inovacijų kultūra) darbo aplinką.

Adresas susirašinèti: janina.ribeliene@gmail.com

Gauta 2019-06-07 